Article

IKRAM, R.M. ${ }^{1}$

TANVEER, A. ${ }^{2 *}$

MAQBOOL, R. ${ }^{2,3}$

NADEEN, M.A. ${ }^{2}$

\section{MODEling THE COMPETITIVE EFFECT OF Euphorbia dracunculoides AND Astragalus sp. IN ZERO INPUT RAINFed ChickPEA}

\section{Modelagem do Efeito Competitivo de Euphorbia dracunculoides e Astragalus sp. em Baixa Produção de Grão de Bico em Cultivo de Sequeiro}

* Corresponding author:

<asiftanveer@uaf.edu.pk>

Received: May 31, 2016

Approved: March 3, 2017

\section{Planta Daninha 2018; v36:e018156247}

Copyright: This is an open-access article distributed under the terms of the Creative Commons Attribution License, which permits unrestricted use, distribution, and reproduction in any medium, provided that the original author and source are credited.
ABSTRACT - Brown chickpea (Cicer arietinum L.) is one of the two chickpea types grown in Pakistan and other countries. The critical period for weed removal in a rainfed chickpea system is an important consideration in devising weed management strategies. Field experiments were conducted in the winter season of 2011 and 2012 to determine the extent of yield loss with different periods of weed crop competition. Seven weed crop competition periods $(0,45,60,75,90,105$ and 160 days after sowing - DAS) were used to identify the critical period for weed removal in rainfed chickpea. Experimental plots were naturally infested with Euphorbia dracunculoides and Astragalus sp. in both years. Individual, composite density and dry weights of E. dracunculoides and Astragalus sp. increased significantly with an increase in the competition period. However, yield and yield-contributing traits of chickpea significantly decreased with an increase in the competition period. Chickpea seed yield loss was $11-53 \%$ in different weed crop competition periods. Euphorbia dracunculoides and Astragalus sp. removed 39.9 and $36.9 \mathrm{~kg} \mathrm{ha}^{-1}$ of N, 9.61 and $7.27 \mathrm{~kg} \mathrm{ha}^{-1}$ of $\mathrm{P}$ and 38.3 and $36.9 \mathrm{~kg} \mathrm{ha}^{-1}$ of $\mathrm{K}$, respectively. Season long weed competition (160 days after sowing) resulted in $19.5 \%$ seed protein content compared with $24.5 \%$ seed protein content in weed-free chickpea. A Logistic equation was fitted to yield data in response to increasing periods of weed crop competition. The critical timing of weed removal at 5 and 10\% acceptable yield losses were 26 and 39 DAS, respectively. The observed critical period suggests that in rainfed chickpea, a carefully timed weed removal could prevent grain yield losses.

Keywords: critical period for weed removal, nutrient losses, grain yield.

RESUMO - O grão de bico Desi (Cicer arietinum L.) é uma das duas variedades de grão de bico cultivadas no Paquistão e em outros países. O período crítico de interferência de plantas daninhas no grão de bico em cultivo de sequeiro é uma consideração importante no planejamento de estratégia para manejo dessas plantas. Foram conduzidos experimentos de campo no inverno de 2011 e 2012, para determinar a dimensão das perdas no rendimento em diferentes periodos de competição das plantas daninhas. Sete períodos de competição $(0,45,60,75,90$, 105 e 160 dias após semeadura - DAS) foram usados para identificar o periodo crítico de interferência das plantas daninhas no grão de bico em cultivo de sequeiro. As parcelas experimentais foram infestadas naturalmente com Euphorbia dracunculoides e Astragalus sp. nos dois anos. A densidade individual e composta e a massa seca de E. dracunculoides e Astragalus sp. aumentaram

1 Department of Agronomy, Pir Mehr Ali Shah Arid Agriculture University, Rawalpindi, Pakistan, ${ }^{2}$ Department of Agronomy, University of Agriculture, Faisalabad, Pakistan, ${ }^{3}$ Precision Agriculture, USPCAS-AFS, University of Agriculture, Faisalabad, Pakistan. 
significativamente com o aumento do período de competição. No entanto, a produção e os fatores determinantes da produção de grão de bico diminuíram significativamente com o aumento do período de competição. A perda no rendimento das sementes de grão de bico foi de 11-53\% em diferentes períodos de competição das plantas daninhas. Euphorbia dracunculoides e Astragalus sp. perderam

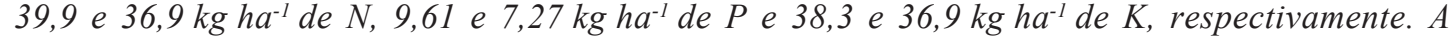
matocompetição ao longo da temporada (160 dias após semeadura) resultou em 19,5\% de teor de proteinas das sementes, em comparação com $24,5 \%$ de teor de proteínas das sementes em grão de bico sem plantas daninhas. A equação logística ajustada para produzir dados de rendimento em resposta ao período crescente de competição de culturas de plantas daninhas mostrou períodos críticos de interferência dessas plantas, com 5 e 10\% de perda de rendimento aceitável aos 26 e 39 DAS, respectivamente. O período crítico observado sugere que, no grão de bico em cultivo de sequeiro, a remoção das plantas daninhas cuidadosamente planejada poderia evitar a perda de rendimento dos grãos.

Palavras-chave: período crítico de interferência de plantas daninhas, perda de nutrientes, produção de grãos.

\section{INTRODUCTION}

Chickpea (Cicer arietinum L.) is the third most important pulse crop of the world, grown for its economic importance and nutritive value (Avola and Patane, 2010). It is grown mainly in dry and semi-dry areas in India, Pakistan and Iran (Mohammadi et al., 2005; Paolini et al., 2006). Pakistan is the second world largest chickpea producer (9.5\%) after India (65\%), followed by Turkey (6.7\%) (Shah et al., 2006). In the world, there are two chickpea types, based on their seed color, named 'Kabuli' or white, and 'desi' or brown (Kaya et al., 2008). Desi chickpea accounts for about $90 \%$ of the world's current commercial production. Chickpea is grown on 0.99 million hectares in Pakistan, with a total production of 0.67 million tons. The "Thal" desesrt contributes about $77 \%$ to the total chickpea production of Pakistan. The "Thal" desert is located between the Jehlum and Sindh rivers, with total length from north to south of 310 kilometers $(\mathrm{km})$, maximum breadth of $110 \mathrm{~km}$, and minimum breadth of $30 \mathrm{~km}$. The soils of Thal desert are alluvial with sand dunes. Rainfalls are below $300 \mathrm{~mm}$, which are unequally distributed around the year. Rainfed chickpea is sown in October-November on soil moisture conserved from summer monsoons (JulySeptember). At farmer fields there is a big gap (2.63 ton. ha $\mathrm{h}^{-1}$ ) between the potential yield (3.3 ton. ha $\mathrm{h}^{-1}$ ) and the average national grain yield ( 0.67 ton. ha $\left.{ }^{-1}\right)$ of chickpea (Govt. of Pakistan, 2013). Many factors are responsible for chickpea yield reduction in Pakistan, including inadequate and erratic rains, low temperature stress (frost) during early crop growth, sowing on marginal land, no fertilizer use, lack of basic weed management knowledge and lack of effective weed control measures in chickpea production. Weed infestation is one of the most important factors responsible for the low yield and economic returns of chickpea (Mohammadi et al., 2005). Chickpea plants develop slowly, with an open design and short height, which limit their ability to compete with weeds (Whish et al., 2002). Weed infestations may reduce yield up to $97 \%$ in chickpea (Paolini et al., 2006; Patel et al., 2006). Polygonum aviculare L., Chenopodium album L., Lolium multiflorum Lam. and Sinapis arvensis L. caused 20-85\% yield at various densities and competition periods (Radicetti et al., 2012a, b; Frenda et al., 2013). Losses due to weeds depend on the competition between crop plants and weeds, which are influenced by weed type, weed density, weed germination time, weed infestation duration, growth space, environmental factors, soil nutrient status and management factors (row spacing, seed rate, tillage, fertilizer and irrigation schedule).

A sound knowledge of weed crop competition is the prerequisite in making right decisions for a suitable weed management, and to reduce its cost (Evans et al., 2003). The critical periods of Euphorbia heterophylla competition were 21-28 days after planting, and 17-44 days after emergence in cowpea (Vigna unguiculata) and soybean (Glycine max), respectively (Olorunmaiye and Ogunfolaju, 2002; Meschede et al., 2002). Mohammadi et al. (2005) identified that chickpea must be kept weed-free between 24 and 48 days after emergence in order to prevent more than $10 \%$ in seed yield losses. Tepe et al. (2011) and Frenda et al. (2013) reported critical periods for weed control 20 days after emergence in warm seasons with continental climate (Turkey), and 
50-69 days after emergence in semiarid Mediterranean climates (Italy), respectively. The ultimate effect of weed competition is to reduce the growth and yield of crops, but determining the way in which yield reduction occurs is important to understand the complex phenomenon of weed crop competition. In order to determine the critical period for weed-crop competition, the weed type is very important. Euphorbia dracunculoides is an annual herb, typically $15-40 \mathrm{~cm}$ tall and often highly branched at its base, with profuse branching capacity, which helps it to quickly cover the soil surface. Euphorbia dracunculoides is one of the most common chickpea weeds in the rainfed areas of Pakistan. Its seeds form a persistent seed bank; they emerge before chickpea and complete their life cycle 15-20 days after chickpea harvest. On the other hand, Astragalus sp. is an annual shrub, which typically achieves the height of $40 \mathrm{~cm}$. Astragalus is also a troublesome weed for chickpea. Astragalus emerges along with chickpea and completes its life cycle at the time of chickpea maturity; therefore, large numbers of seeds are dispersed in chickpea fields and are ultimately deposited into the soil seed bank.

Euphorbia dracunculoides has been studied; this includes information such as allelopathic effects and control in laboratory experiments. However, these investigations did not address the competitive effects of $E$. dracunculoides. On the other hand, there are no works on Astraglus sp. Therefore, the present study was planned with the purposes to find out the critical period for E. dracunculoides and Astragalus sp. removal in chickpea, and their impact on the growth and reproductive behavior of chickpea.

\section{MATERIALS AND METHODS}

Competition of E. dracunculoides and Astragalus sp. in rainfed chickpea was studied under farmer field conditions, with the goal to determine the critical period for weed removal, in the Thal area of the Khushab district (32.84 $\mathrm{N}$, latitude and $71.86^{\circ} \mathrm{E}$, longitude), Punjab Province, Pakistan. With an average temperature and annual rainfall of $19.60{ }^{\circ} \mathrm{C}$ and $237 \mathrm{~mm}$, respectively, chickpea growth is restricted to the period between October and April. The experimental soil was sandy loam, with $0.48 \%$ organic matter, a $\mathrm{pH}$ of 8.3 ; the available $\mathrm{P}, \mathrm{K}$ and $\mathrm{N}$ contents in the upper $45 \mathrm{~cm}$ of soil were $5.96 \mathrm{mg} \mathrm{kg}^{-1}, 237 \mathrm{mg} \mathrm{kg}^{-1}$ and $0.033 \%$, respectively.

The experiment was laid out as randomized complete block design with four replications in both years (2010-11 and 2011-12). Plots were maintained weed-free or weedy for the required durations. In weed-free plots (zero competition), weed removal was started immediately after emergence and the plots were kept weed-free till crop harvest. In weedy plots, weeds were allowed to compete with chickpea for 45, 60, 75, 105 and 160 (whole weedy season) days after sowing (DAS). After each prescribed competition period, the plots were kept weed-free till harvesting. Weeds were removed by hand hoeing between rows and by hand pulling along the rows. The crop was planted in the field, where heavy infestation of E. dracunculoides and Astragalus sp. had been reported in previous years. The crop was sown on the residual moisture of July-September rainfalls. No land preparation was performed before chickpea sowing during both years of experimentation. Chickpea variety "Pb-2008" was sown in the last week of October 2010 and October 2011 in $30 \mathrm{~cm}$ distant rows by tractor mounted drills, using a recommended seed rate of $60 \mathrm{~kg} \mathrm{ha}^{-1}$ at a $15-20 \mathrm{~cm}$ sowing depth. The plot size was maintained at $5.0 \mathrm{~m} \times 1.8 \mathrm{~m}$. Thinning was done one week after the emergence of chickpea, in order to maintain a plant to plant distance of $15 \mathrm{~cm}$. Chickpea monocropping is practiced in the area as well as at our experimental site. Experimental site was managed under standard practices with no fertilizer and no irrigation were applied to the crop. All weeds other than E. dracunculoides and Astragalus sp. (e.g. Asphodelus tenuifolius Cav., Chenopodium album L. and Convolvulus arvensis L.) were manually removed whenever they emerged.

All six rows of matured chickpea were hand-harvested, and the grains were threshed manually by stick beating. Yield was based on grain weight, adjusted to $13 \%$ moisture. Observations on weeds were made at the end of each prescribed competition period from an area of $1 \mathrm{~m}^{2}$. The contribution of an individual weed species to the weed community was determined by its two factor summed dominance ratio (SDR) (Janiya and Moody, 1989) values expressed as a percentage.

Oven-dried samples of $E$. dracunculoides and Astragalus sp. were ground with a grinder and NPK contents (\%) were determined, as suggested by AOAC (1984). NPK concentrations in 
E. dracunculoides and Astragalus sp. were multiplied with the dry weight of the respective weed, in order to calculate N, P and K uptakes by E. dracunculoides and Astragalus sp.

\section{Statistical analyses}

Data on individual and composite density, dry weight, nutrient uptake of $E$. dracunculoides and Astragalus sp., yield and yield components, and grain protein contents of chickpea were subjected to analysis of variance (ANOVA) using a Mixed procedure in the Statistical Analysis System (Littell et al., 2006; SAS, 2008). Statistical analyses were performed for two years (2010 and 2011) using a linear mixed model with factor of interest (five weed crop competition periods viz. $0,45,60,75,90,105$ and 160 DAS) as fixed effects, while year and blocks were random effects, as such inferences on the random effects can be extended to other years and blocks. Constant variance and normal distribution assumptions on the error terms were verified by examining the residuals (Montgomery, 2009). Mean comparisons were conducted using the TukeyKramer test $(p<0.05)$ within the SAS Mixed procedure. Letter displays for the mean comparisons were created with the \%pdmix800 macro by Saxton (1998).

A three parameter logistic equation was used to describe the effect of increasing durations of $E$. dracunculoides and Astragalus sp. competition on the relative yield of rainfed chickpea. The year and blocks considered to be random effects to broaden the inferences were in line with the procedure suggested by Knezevic et al. (2002). The parameters of the nonlinear model were estimated iteratively using the NLMIXED Procedure of SAS (SAS, 2008).

$$
\mathrm{Y}=\left(\left(1 /\left(\mathrm{EXP}\left(\mathrm{K}^{*}(\mathrm{~T}-\mathrm{X})\right)+\mathrm{F}\right)\right)+((\mathrm{F}-1) / \mathrm{F})\right){ }^{*} 100
$$

where $\mathrm{Y}$ is the yield (\% of season-long weed-free control), $\mathrm{T}$ is the time ( $\mathrm{x}$-axis expressed in days after sowing [DAS], $\mathrm{X}$ is the point of inflection (DAS), $\mathrm{K}$ and $\mathrm{F}$ are constants (Hall et al., 1992).

\section{RESULTS AND DISCUSSIONS}

At the end of each prescribed competition period, density and dry weight of $E$. dracunculoides and Astragalus species, and composite (total of E. dracunculoides and Astragalus species) weeds differ significantly (Table 1). There was an increase in individual and composite weed density and dry weight with an increase in the weed-crop competition period. Weed density ranged from 43.8 to 90.6 plants per square meter for E. dracunculoides, and 25.8 to 60.8 plants per square meter for Astragalus species. The above ground dry weight of weeds ranged from 264.2 to 419.8 and 143.8 to $276.0 \mathrm{gm}^{-2}$ for E. dracunculoides and Astragalus, respectively. E. dracunculoides exhibited a higher weed infestation in terms of density and dry weight. Increased weed crop competition periods resulted in maximum weed density where weeds took more growing time. SDR is more informative than any other single measure in reflecting the contribution of a weed species in a weed community. Euphorbia dracunculoides was the dominant weed (SDR 64.78$54.98 \%$ ) followed by Astragalus sp., with an SDR of 36.07-40.17 (Figure 1). A higher SDR in E. dracunculoides was due to its ability to emerge earlier and to produce more seeds than Astragalus sp.

Table 1 - Effect of weed competition periods on weed density and dry weight in chickpea

\begin{tabular}{|c|c|c|c|c|c|c|}
\hline \multirow{2}{*}{$\begin{array}{c}\text { Competition } \\
\text { period } \\
\text { (days after sowing) }\end{array}$} & \multicolumn{2}{|c|}{ Individual weed density $\left(\mathrm{m}^{-2}\right)$} & \multirow{2}{*}{$\begin{array}{c}\text { Composite } \\
\text { weed density } \\
\left(\mathrm{m}^{-2}\right)\end{array}$} & \multicolumn{2}{|c|}{$\begin{array}{c}\text { Individual weed dry weight } \\
\left(\mathrm{g} \mathrm{m}^{-2}\right)\end{array}$} & $\begin{array}{c}\text { Total weed } \\
\text { dry weight } \\
\left(\mathrm{g} \mathrm{m}^{-2}\right)\end{array}$ \\
\hline 45 & $43.8 \mathrm{f}$ & $25.8 \mathrm{e}$ & $69.6 \mathrm{f}$ & $264.2 \mathrm{e}$ & $143.8 \mathrm{e}$ & $408.0 \mathrm{e}$ \\
\hline 60 & $55.5 \mathrm{e}$ & $33.7 \mathrm{~d}$ & $89.2 \mathrm{e}$ & $297.8 \mathrm{~d}$ & $180.3 \mathrm{~d}$ & $478.1 \mathrm{~d}$ \\
\hline 75 & $72.0 \mathrm{~d}$ & $42.9 \mathrm{c}$ & $114.9 \mathrm{~d}$ & $353.3 \mathrm{c}$ & $224.6 \mathrm{c}$ & $577.8 \mathrm{c}$ \\
\hline 90 & $79.7 \mathrm{c}$ & $52.9 \mathrm{~b}$ & $132.6 \mathrm{c}$ & $382.4 \mathrm{~b}$ & $256.9 \mathrm{~b}$ & $639.2 \mathrm{~d}$ \\
\hline 105 & $86.2 \mathrm{~b}$ & $58.4 \mathrm{a}$ & $144.5 \mathrm{~b}$ & $397.4 \mathrm{ab}$ & $270.9 \mathrm{ab}$ & $668.3 \mathrm{a}$ \\
\hline 160 & $90.6 \mathrm{a}$ & $60.8 \mathrm{a}$ & $151.4 \mathrm{a}$ & $409.8 \mathrm{a}$ & $276.0 \mathrm{a}$ & $685.7 \mathrm{a}$ \\
\hline
\end{tabular}

Means sharing the same letter in a column are not significantly different at the $5 \%$ level of significance by Tukey-Kramer test. 


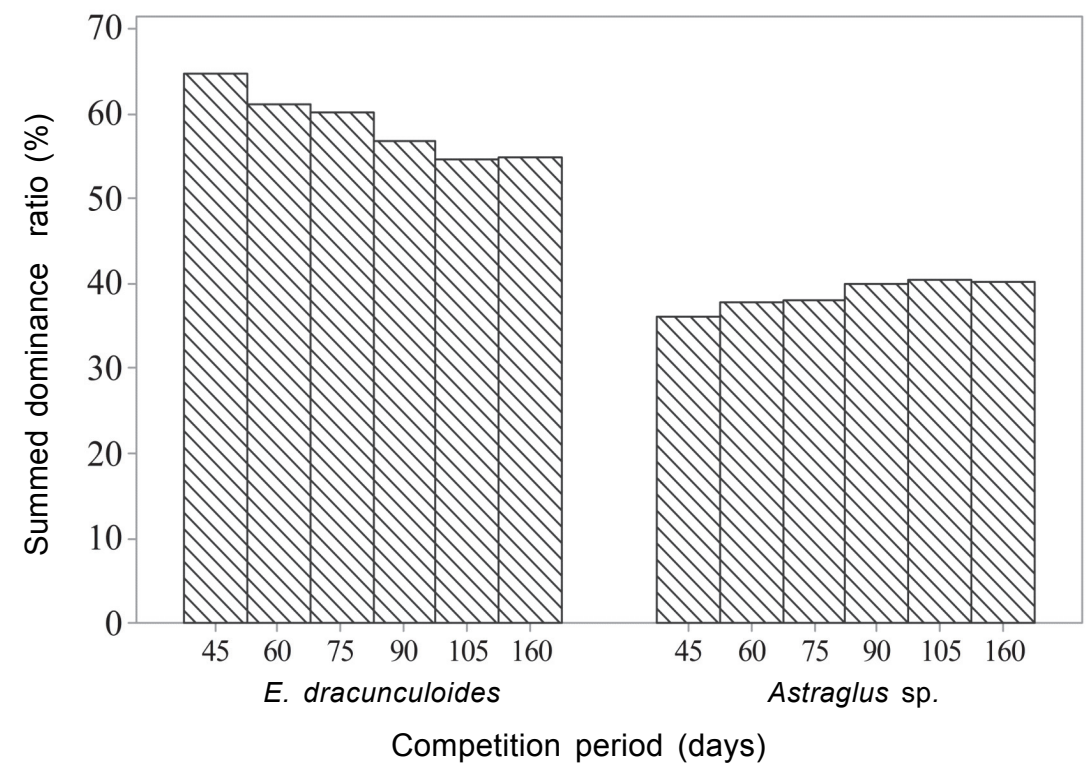

Figure 1 - Effect of weed competition periods on the summed dominance ratio of Euphorbia dracunculoides and Astragalus sp.

Euphorbia dracunculoides and Astragalus sp. differ in nutrient (N, P and K) uptake at early competition stages. However, they exhibited non significant variations in nutrient uptake at later competition stages (Table 2). Both weed species registered a significantly greater uptake of NPK at 90 or beyond 90 DAS weed-crop competition. The competitive ability of weeds to uptake nutrients might not have been acute in the early stages, due to less population and growth. However, when the weeds grow older, the demand for nutrients also increased. The weed greater uptake of nutrients is, therefore, more perceptible at 90 days of weed-crop competition period. Nutrient uptake increased with increases in weed crop competition periods, due to higher weed density and biomass. Similarly, Gaikwad and Pawar (2003) reported that weeds removed $33.53 \mathrm{~kg} \mathrm{ha}^{-1}$ of $\mathrm{N}$ and $15.78 \mathrm{~kg} \mathrm{ha}^{-1}$ of $\mathrm{P}$ in weedy plots in soybean crop.

There was a significant variation in number of secondary branches, pods per plant, seeds per pod and 100 seed weight of chickpea in different weed-crop competition durations (Table 3). The highest chickpea yield traits were recorded from plots in which E. dracunculoides and Astragalus sp. were left for the shortest period (45 DAS) (Table 3). Chickpea yield traits from plots kept weedy for 105 and 160 days after sowing were not significantly different from each other. These results showed that the presence of weeds beyond 45 DAS affected more adversely the yield traits of chickpea. This may be explained by the lower occurrence of weed sensitivity by chickpea at early stages. The variations observed in the yield traits of chickpea were mainly attributed to variations in the duration of weed-crop competition. Reduction in primary branches

Table 2 - Effect of weed competition periods on the NPK uptake of weeds in chickpea

\begin{tabular}{|c|c|c|c|c|c|c|}
\hline $\begin{array}{c}\text { Competiti } \\
\text { on period } \\
\text { (days after } \\
\text { sowing) }\end{array}$ & \multicolumn{2}{|c|}{ N-uptake $\left(\mathrm{kg} \mathrm{ha}^{-1}\right)$} & \multicolumn{2}{c|}{ P-uptake $\left(\mathrm{kg} \mathrm{ha}^{-1}\right)$} & \multicolumn{3}{c|}{${\text { K-uptake }\left(\mathrm{kg} \mathrm{ha}^{-1}\right)}^{-1}$} & & & \\
\hline & E. dracunculoides & Astragalus sp. & E. dracunculoides & Astragalus sp. & E. dracunculoides & Astragalus sp. \\
\hline 40 & $34.4 \mathrm{c}$ & $23.7 \mathrm{~d}$ & $7.95 \mathrm{c}$ & $5.44 \mathrm{c}$ & $29.4 \mathrm{c}$ & $18.3 \mathrm{~d}$ \\
\hline 60 & $36.2 \mathrm{bc}$ & $27.9 \mathrm{c}$ & $8.28 \mathrm{bc}$ & $6.31 \mathrm{bc}$ & $31.9 \mathrm{~b}$ & $22.3 \mathrm{c}$ \\
\hline 75 & $37.6 \mathrm{~b}$ & $33.2 \mathrm{~b}$ & $8.60 \mathrm{abc}$ & $6.78 \mathrm{ab}$ & $36.6 \mathrm{a}$ & $27.3 \mathrm{~b}$ \\
\hline 90 & $39.3 \mathrm{a}$ & $36.4 \mathrm{a}$ & $8.97 \mathrm{abc}$ & $6.93 \mathrm{ab}$ & $38.1 \mathrm{a}$ & $30.2 \mathrm{a}$ \\
\hline 105 & $39.4 \mathrm{a}$ & $36.6 \mathrm{a}$ & $9.09 \mathrm{ab}$ & $7.14 \mathrm{ab}$ & $38.2 \mathrm{a}$ & $30.7 \mathrm{a}$ \\
\hline 160 & $39.9 \mathrm{a}$ & $36.9 \mathrm{a}$ & $9.61 \mathrm{a}$ & $7.27 \mathrm{a}$ & $38.3 \mathrm{a}$ & $31.0 \mathrm{a}$ \\
\hline
\end{tabular}

Means sharing the same letter in a column are not significantly different at the $5 \%$ level of significance by Tukey-Kramer test. 
IKRAM, R.M. et al. Modeling the competitive effect of Euphorbia dracunculoides and Astragalus sp. in zero input ...

Table 3 - Effect of weed competition periods on yield, yield traits and protein content of chickpea

\begin{tabular}{|c|c|c|c|c|c|c|}
\hline $\begin{array}{c}\text { Competition } \\
\text { period (days } \\
\text { after sowing) }\end{array}$ & $\begin{array}{c}\text { No. of } \\
\text { secondary } \\
\text { branches per } \\
\text { plant }\end{array}$ & $\begin{array}{c}\text { No. of pods per } \\
\text { plant }\end{array}$ & $\begin{array}{c}\text { No. of seeds } \\
\text { per pod }\end{array}$ & $\begin{array}{c}\text { 100-seed } \\
\text { weight } \\
(\mathrm{g})\end{array}$ & $\begin{array}{c}\text { Seed yield } \\
\left(\mathrm{kg} \mathrm{ha}^{-1}\right)\end{array}$ & $\begin{array}{c}\text { Protein content } \\
(\%)\end{array}$ \\
\hline 0 & $22.1 \mathrm{a}$ & $66.5 \mathrm{a}$ & $2.47 \mathrm{a}$ & $22.7 \mathrm{a}$ & $2353 \mathrm{a}$ & $24.5 \mathrm{a}$ \\
\hline 45 & $18.2 \mathrm{~b}$ & $58.4 \mathrm{~b}$ & $2.22 \mathrm{ab}$ & $21.9 \mathrm{a}$ & $2019 \mathrm{~b}$ & $23.6 \mathrm{ab}$ \\
\hline 60 & $16.1 \mathrm{bc}$ & $52.4 \mathrm{c}$ & $2.02 \mathrm{bc}$ & $21.0 \mathrm{ab}$ & $1797 \mathrm{c}$ & $22.3 \mathrm{abc}$ \\
\hline 75 & $14.4 \mathrm{~cd}$ & $43.7 \mathrm{~d}$ & $1.80 \mathrm{~cd}$ & $19.4 \mathrm{bc}$ & $1515 \mathrm{~d}$ & $21.9 \mathrm{bcd}$ \\
\hline 90 & $11.9 \mathrm{de}$ & $39.2 \mathrm{~d}$ & $1.63 \mathrm{~d}$ & $18.2 \mathrm{~cd}$ & $1327 \mathrm{e}$ & $20.8 \mathrm{~cd}$ \\
\hline 105 & $10.4 \mathrm{e}$ & $32.1 \mathrm{e}$ & $1.52 \mathrm{~d}$ & $16.7 \mathrm{~d}$ & $1130 \mathrm{f}$ & $19.8 \mathrm{~cd}$ \\
\hline 160 & $10.3 \mathrm{e}$ & $30.4 \mathrm{e}$ & $1.47 \mathrm{~d}$ & $16.0 \mathrm{~d}$ & $1103 \mathrm{f}$ & $19.5 \mathrm{~d}$ \\
\hline
\end{tabular}

Means sharing the same letter in a column are not significantly different at the $5 \%$ level of significance by Tukey-Kramer test.

of chickpea with an increase in the number of days for competition could be due to the lower availability of space for the lateral growth of chickpea, and to the higher competition imposed by weeds. Chickpea crops might have taken full advantage of resources which have facilitated its growth and development in absence of weed plants in weed-free plots. Therefore, weed-free plots produced more pods per plant (66.5). On the other hand, weed plants that remained in association with chickpea for specified periods or entire growing seasons negatively impacted the grain yield and yield-contributing traits of chickpea by competing for the limited resources. Weed crop competition for a longer period of time eventually resulted into a lower number of pods per plant in chickpea (30.4 pods in 160 days weed-crop competition). Furthermore, reduced accessibility of chickpea to space due to higher competition periods may possibly explain the lower number of pods. Reduction in number of seeds per pod (10.12-40.48\%) and 100 seed weight (3.52-41.87\%) of chickpea in different weed-crop competition periods compared to zero competition might be due to the reduction in the availability of light, moisture, space and nutrients, which resulted in the reduced production of photosynthates and, ultimately, in the translocation to chickpea seeds. Olorunmaiye and Ogunfolaju (2002) reported reductions in yield components of cowpea with an increase in E. heterophylla competition duration beyond 4 weeks after planting. These findings are also in line with results by Mohammadi et al. (2005), who reported that the prolonged presence (beyond 50 days after emergence) of weeds caused reduction in number of branches, pods per plant and 100- seed weight of chickpea. Aslam et al. (2007) also reported decreases in the number of seeds per pod of chickpea with an increase in competition duration.

Seed yield of rainfed chickpea decreased significantly as the duration of the competition increased (Table 3). The highest seed yield $\left(2,353 \mathrm{~kg} \mathrm{ha}^{-1}\right)$ was obtained in weed-free plots and the minimum seed yield $\left(1,103 \mathrm{~kg} \mathrm{ha}^{-1}\right)$ was recorded in a 160 day competition period, which was $53.2 \%$ lower than weed-free plots (Table 3). Chickpea yield losses (13 to 53\%) due to weed competition varied according to the duration of weed competition. Longer weed-crop competition (105 and 160 DAS) resulted in 51.45 and 53.41\% yield reductions, respectively, but these reductions were not significantly different from each other. Chickpea yield losses due to weed competition are a major constraint in chickpea production in the Mediterranean region (Radicetti et al., 2012b). Yield reductions with increasing weed chickpea competition periods are a likely result of biomass accumulation and nutrient uptake of weeds. Further decreases in chickpea yield with increased competition periods were due to decreases in the major seed yield components, such as number of pods per plant, number of grains per pod and 100-seed weight. These results are in line with those by Radicetti et al. (2012a,b), who found that the chickpea seed yield was reduced on an average by $20-67 \%$ when crops remained infested with weeds until harvesting, compared with weed-free ones. Mohammadi et al. (2005) found an average yield reduction that was slightly higher than 50\% in chickpea, whereas Tepe et al. (2011) observed 25 to $31 \%$ losses due to weed competition. Seed yield was $85 \%$ less in weed check plots as compared with the weed free plots (Frenda et al., 2013).

The variability in these results shows that the impact of weed competition on chickpea yield depends on the variability in the climatic and agronomic conditions in which the experiments 
were conducted, the differences in weed density and competitiveness of weeds, and the differences in the weed infestation periods. The results also revealed that weed-crop competition with extended competition duration had an adverse effect on the yield potential of chickpea.

The protein content of chickpea seeds was significantly higher in weed free plots, 45 and 60 DAS weed-crop competition than in the rest of the competition durations (Table 3). The nitrogen uptake by weeds was higher where weeds were allowed to compete with chickpea for longer periods, so the $\mathrm{N}$ percentage in chickpea seeds was lower and, consequently, there was a low seed protein content. Yadav at al. (2007) also reported a decrease in the protein content of chickpea seeds, as a result of a season-long weed competition.

The critical period for weed removal (CPWR) at 5 and $10 \%$ acceptable yield losses (AYL) was 26 and 39 DAS, respectively, in rainfed chickpea (Figure 2). Coefficients for the parameters used to fit the logistic model are listed in Table 4. These results are in accordance with the ones by Mohammadi et al. (2005), which show that CPWR was between the first 22 days and 56 days in order to prevent a 10\% AYL excess in chickpea. Frenda et al. (2013) reported 37 and 53 days after emergence as the CPWR at 5\% AYL in chickpea. Although critical periods vary among crops, site and years, CPWR provides useful information to growers about the best period to control weeds (Norsworthy and Oliveira, 2004). A period of 21-28 days after planting (Olorunmaiye and Ogunfolaju, 2002) and 17-44 days after emergence (Meschede et al., 2002) is the critical period of $E$. heterophylla competition in cowpea and soybean, respectively. Our findings and those of other researchers show that the CPWR is highly dependent on species, density,

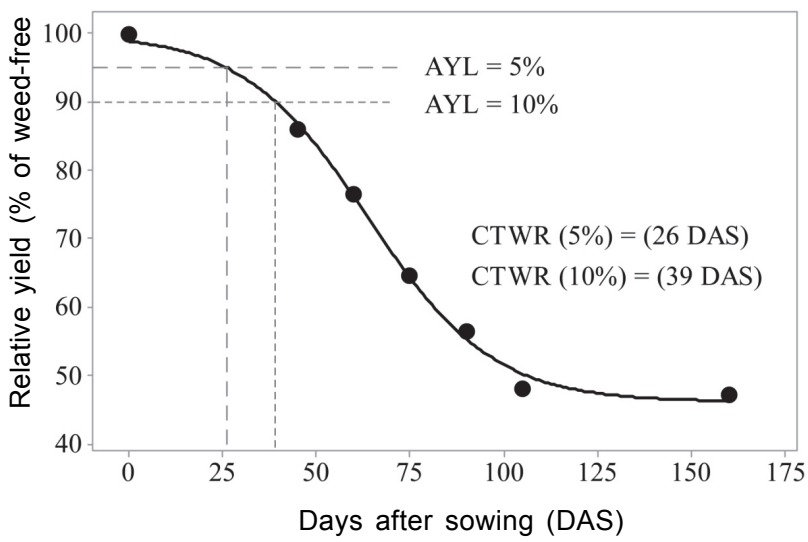

Logistic equation was fitted to yield (\% of weed-free yield). Parameter estimates of the equations are provided in Table 4 . The critical period for weed removal (CPWR) to achieve $5 \%$ and $10 \%$ of acceptable yield loss (AYL) are provided between the broken vertical lines.

Figure 2 - Effect of weed control timings on chickpea yield (weedy yield up to harvesting). competitiveness and emergence periodicity of the weed flora in crop competition and climatic conditions, soil type and source of moisture. The results of this research also show that E. dracunculoides and Astragalus sp. are a serious constraint in successfully growing chickpea in rainfed areas. Hence, to ensure high yield in rainfed chickpea, it is necessary to implement adequate weed control measures at 39 DAS.

Table 4 - Coefficient estimates to determine the effect of timing weed removal on relative chickpea yield, using a logistic model

\begin{tabular}{|c|c|c|}
\hline \multicolumn{3}{|c|}{ Coefficient } \\
\hline $\mathrm{X}$ & $\mathrm{K}$ & $\mathrm{F}$ \\
\hline $53.6(1.73)$ & $0.059(0.0051)$ & $1.85(0.047)$ \\
\hline
\end{tabular}

Data fit to equation, where $\mathrm{X}$ is the point of inflection (DAS), K and $\mathrm{F}$ are constants.

\section{ACKNOWLEDGEMENTS}

We gratefully acknowledge the Higher Education Commission, Islamabad, Pakistan, for providing the financial support to conduct this research.

\section{REFERENCES}

Association of Official Analytical Chemists- AOAC. Official methods of analysis of the AOAC. 14 ${ }^{\text {th }}$.ed. Washington, DC: 1984.

Aslam M. et al. Effect of sowing methods and weed control techniques on yield and yield components of chickpea (Cicer arietinum L.). Pak J Weed Sci Res. 2007;13(1-2):49-61. 
Avola G., Patane C. Variation among physical, chemical, and technological properties in three Sicilian cultivars of chickpea (Cicer arietinum L.). Int J Food Sci Technol. 2010;45(12):2565-72.

Evans S.P. et al. Nitrogen application influences the critical period for weed control in corn. Weed Sci. 2003;51(3):408-17.

Frenda A.S. The critical period of weed control in Faba Bean and Chickpea in Mediterranean. Weed Sci. 2013;61(3):452-9.

Gaikwad R.P., Pawar V.S. Effect of herbicides on soybean crop and weeds. Indian J. Weed Sci. 2003;35(1):145-7.

Govt. of Pakistan. Ministry of Finance. Economic Survey of Pakistan. Islamabad: 2013. 23p.

Hall M.R. et al. The critical period of weed control in grain corn (Zea mays L.). Weed Sci. 1992;40(3):1-447.

Janiya J.D., Moody K. Weed populations in transplanted and wet-seeded rice as affected by weed control method. Trop Pest Manage. 1989;35(1):8-11.

Kaya M. et al. Interaction between seed size and $\mathrm{NaCl}$ on germination and early seedling growth of some Turkish cultivars of chickpea (Cicer arietinum L.). J Zhejiang Univ Sci. 2008;9(5):371-7.

Knezevic S.Z. et al. Critical period for weed control: The concept and data analysis. Weed Sci. 2002;50(6):773-86.

Littell R.C., Milliken G.A., Stroup W.W., Wolfinger R.D., Schabenberger O. SAS ${ }^{\circledR}$ for Mixed Models. $2^{\text {nd }}$. ed. Cary, NC: SAS Institute, 2006.

Meschede D.K. et al. Critical period of interference of Euphorbia heterophylla in soyabean crop under low seeding rate. Planta Daninha. 2002;20(3):381-7.

Mohammadi G. et al. Critical period of weed interference in chickpea. Weed Res. 2005;45(1):57-63.

Montgomery D.C. Design and analysis of experiments. $7^{\text {th }}$. ed. New York: Wiley, 2009.

Norsworthy J.K., Oliveira M.J. Comparison of the critical period for weed control in wide and narrow row corn. Weed Sci. 2004;52(5):802-7.

Olorunmaiye K.S., Ogunfolaju T.R. The effect of density and duration of Euphorbia heterophyll (L.) on the performance of cowpea (Vigna unguiculata) (Walp). NISEB J. 2002;2(1):17-22.

Paolini R. et al. Competitive interactions between chick-pea genotypes and weeds. Weed Res. 2006;46(4):335-44.

Patel B.D. et al. Effect of fertilizers and weed management practices on weed control in chickpea (Cicerarietinum L.) under middle Gujarat conditions. Ind J Crop Sci. 2006;1(1-2):180-3.

Radicetti E. et al. Combined effect of genotype and inter row tillage on yield weed control of chickpea (Cicer arietinum L.) in a rainfed Mediterranean environment. Field Crop Res. 2012a;127(3):161-9.

Radicetti E. et al. The competitive ability of different chickpea (Cicer arietinum) genotypes against Polygonum aviculare under field conditions. Crop Prot. 2012b;42(12):312-9.

SAS Institute Inc. 2008. SAS 9.2 user's guide. Cary, NC: USA.

Saxton A.M. A macro for converting mean separation output to letter groupings In: Proceedings 23rd Mixed. Saxton: SAS Users Group Intl., SAS Institute, 1998. p.1243-6.

Shah T.M. et al. Induced genetic variability in chickpea (Cicerarietinum L.) I. Frequency and spectrum of chlorophyll mutations. Pak J Bot. 2006;38(4):1217-26.

Tepe I. et al. Critical period of weed control in chickpea under non-irrigated conditions. Turk J Agric For. 2011;35(5):525-34.

Whish J.P.M. et al. The effect of row spacing and density on yield loss of chickpea. Aust J Agric Res. 2002;53(12):1335-40.

Yadav P.K. et al. Effect of herbicides on biochemical and growth parameters of chickpea (Cicer arietinum). Ind J Agric Sci. 2007;77(8):542-3. 